\title{
AS VICISSITUDES DO "ENSAIO SOBRE O DOM"*
}

Lygia Sigaud

A partir dos anos 60, antropólogos de diferentes tradições nacionais passaram a convergir no sentido de considerar que o texto de M arcel M auss, "Ensaio sobre o Dom: Forma e Razão da Troca nas Sociedades Arcaicas" (1991[1923-24]), contivesse uma teoria da troca, que atribui à identificação entre a coisa dada e o espírito do doador o princípio de explicação das transações. Desde então esta tese ganhou força e acabou por se consolidar, como o atestam, dentre outros, sua incorporação no verbete "troca" da Encyclopedia of Social and Cultural Anthropology (Carrier 1997 [1996]:220-221) e na biografia de Marcel Mauss (Fournier 1994:520).

Ora, esta representação do texto dos anos 20 , centrada na "troca" e nos seus "aspectos espirituais", contrasta fortemente com a que tiveram os contemporâneos de $M$ auss, os quais resgataram suas dimensões relativas ao direito, às obrigações e às prestações totais. Assim, Henry LévyBruhl, em resenha para a Revue Historique du Droit Français et Etranger, destacava que o autor havia prestado uma "ajuda inesperada e das mais eficazes à história e à pré-história do direito" e fornecido a prova de que "a história das obrigações pode também receber do estudo das sociedades inferiores vários esclarecimentos" (Fournier 1994:521)1. O tema do direito foi também aquele que despertou a atenção de Bronislaw Malinowski: em carta a M auss, no final de 1925, comentando sua publicação no Année Sociologique, dizia haver chegado a conclusões semelhantes às suas, trabalhando sobre problemas do direito em livro então no prelo (Fournier 1994:524).

A percepção de que havia ocorrido uma descontinuidade na interpretaçao do "Ensaio sobre o Dom", doravante ED, deu-se no âmbito de uma pesquisa que, por tratar dos fluxos de dons e contra-dons, levou-me a retomar o artigo do Année Sociologique e a percorrer a vasta literatura a ele referido². Foi ao chegar aos trabalhos das últimas décadas, como de Sahlins (1974[1970]), Parkin (1976), Tambiah (1993[1984]), Guidieri 
(1984), Weiner (1992) e Godelier (1996) que constatei a aludida adesão quase que maciça à idéia-força a respeito do texto, assim como uma indiferença em relação às preocupações de M auss com direitos e obrigações e ainda uma notável convergência no sentido de fundar interpretações sempre a partir da passagem do texto que lida com a etnografia maori. Chamou-me também a atenção que, entre historiadores que se inspiraram no ED, como Paul Veyne (1976:15-181), por exemplo, e entre estudiosos da escola sociológica francesa, como Vogt (1983:177-198), a "tese" não tivesse encontrado eco.

Comecei então a me perguntar sobre o significado destas vicissitudes do trabalho de M auss, na leitura que dele fizeram os antropólogos. $O$ problema residia em entender como a inflexão havia se produzido. $M$ as, como enfrentá-lo sem voltar ao texto de 1924-25? Este pareceu-me ser um um ponto de partida incontornável para encontrar elementos de resposta: era preciso nele localizar, e com precisão, o que havia sido destacado, como a teoria da troca, o espírito do doador, o direito, as obrigações e as prestações totais. Não podia, no entanto, fazê-lo limitando-me tãosomente a pinçar tais temas no texto. Este procedimento, de praxe em muitos escritos sobre o ED (mas não apenas) e do qual os comentários de Augé (1999:6-7) constituem o exemplo mais recente, supõe necessariamente a adoção de um ponto de vista para realizar a seleção. Não sendo nunca explicitado, tudo que nele há de arbitrário se naturaliza. Daí que uns temas sejam priorizados em detrimento de outros, talvez até mais caros explicitamente ao autor do trabalho comentado. Deixei de lado então os "temas" e centrei-me no plano do trabalho. Procurei acompanhá-lo passo a passo, tal qual as etapas de uma equação, sem "pular" nenhuma delas, para não errar no final, i.e., perder o fio do pensamento do autor. Em seguida, tratei de rastrear as referências ao ED. Não busquei esgotá-las - tarefa inviável e sem pertinência para o meu objeto -, mas reinscrevê-las em uma crononologia precisa, que permitisse indicar o momento em que a inflexão na leitura havia se produzido, sempre tendo o cuidado de identificar quem estava dizendo exatamente o que sobre o texto e como o fazia. Preocupei-me em assumir em relação aos autores uma postura compreensiva, no sentido weberiano do termo, tentando entender, sempre que evidências houvesse, o sentido que poderia ter para eles as apreciações que faziam sobre o trabalho de Mauss.

O que se segue é o resultado destes investimentos no sentido de tornar inteligível o destino do ED. Ao problematizar o que não foi até aqui objeto de atenção dos comentadores do trabal ho de M auss, estarei também explorando uma questão cara aos antropólogos quando se trata de 
lidar com os nativos, mas, via de regra, ignorada quando está em jogo a reflexão acerca das idéias dos colegas: como se constituem e reproduzem as representações acerca de um texto?

\section{0 ensaio no seu tempo}

J urista de formação e agrégé em filosofia, M arcel Mauss tinha 46 anos quando publicou o ED. Ocupava então a cátedra, para a qual havia sido eleito em 1901, de História das Religiões dos Povos Primitivos e não Civilizados, na Ecole Pratique des Hautes Etudes, Seção das Ciências Religiosas. O texto, de 134 páginas e cerca de 500 notas, é constituído por uma introdução, três capítulos e uma conclusão. Os fatos etnográficos são o objeto dos dois primeiros capítulos. No terceiro, M auss dedica-se à análise do direito em civilizações antigas. A conclusão, por sua vez, está desdobrada em três partes: conclusões morais, conclusões de sociologia política e de economia política e conclusões de sociologia geral e moral.

M auss inicia o ED anunciando que seu tema são as trocas que se fazem sob a forma de presentes, em teoria voluntários, mas na realidade obrigatoriamente dados e retribuídos. $O$ estudo estava relacionado a um conjunto mais amplo de investigações sobre o regime do direito contratual e os sistemas de prestações econômicas entre grupos e subgrupos das sociedades ditas primitivas e arcaicas. Os fatos de que iria tratar eram fenômenos sociais "totais" - como os denomina - nos quais se exprimiam todas as espécies de instituições: religiosas, jurídicas e morais (sendo estas políticas e familiares ao mesmo tempo); econômicas (que supõem formas particulares de produção e de consumo); e ainda fenômenos estéticos e morfológicos (:147).

Dentre temas complexos e fatos múltiplos, Mauss afirma que selecionaria um traço a ser examinado: o caráter voluntário, aparentemente livre e gratuito, no entanto coercitivo e interessado, do que chamava de prestações, as quais quase sempre se revestiam da forma do presente oferecido generosamente, mesmo quando no gesto que acompanhava a transação não existia senão ficção, formalismo e mentira social, obrigação e interesse econômico. E levava a seleção mais adiante, ao precisar que, dos diversos princípios que deram o aspecto assinalado à troca, propunha-se a estudar apenas um, por meio de duas perguntas: qual a regra de direito e de interesse que faz com que, nas sociedades de tipo atrasado ou arcaico, o presente recebido seja obrigatoriamente retribuído; que força há na coisa dada que faz com que o destinatário a restitua. 
As questões que estava formulando, acreditava Mauss, apontavam na direção de novos problemas: os referentes a uma forma permanente da moral contratual, notadamente o modo como o direito real permanecia ainda ligado ao direito pessoal; e aqueles que dizem respeito às formas e às idéias que presidiram, pelo menos em parte, a troca e ainda hoje suprem, também em parte, a noção de interesse individual. $O$ objetivo do trabalho era duplo: de um lado fazer uma espécie de arqueologia sobre a natureza das transações humanas, por meio da descrição de fenômenos de troca e de contrato, assim como encontrar a moral e a economia que Ihe eram solidárias; de outro, mostrar que esta moral e economia funcionam ainda em "nossas" 3 sociedades de modo constante, e daí extrair conclusões de ordem moral sobre problemas postos pela crise de "nosso direito" e de "nossa economia".

Foi desta forma, quase que literal mente transcrita aqui, que Mauss definiu os problemas, o interesse e os objetivos do trabalho. Como método, assinalou que se serviria da comparação precisa: isto significava estudar o tema em determinadas áreas - Polinésia, M elanésia e Noroeste americano - e em al guns grandes direitos, em relação aos quais havia documentos que permitiam o acesso à "consciência das sociedades"; e fazê-lo descrevendo cada um dos sistemas, em sua integridade, em vez de comparar apenas traços, procedimento que descaracterizaria as instituições e os documentos.

\section{As peças do quebra-cabeça}

O estabelecimento de relações entre fatos do Noroeste americano, Polinésia, M elanésia e dos direitos arcaicos, foi o produto de um longo caminho percorrido por Mauss. Para além das pesquisas que vinha desenvolvendo, em colaboração com Davy, sobre as formas primitivas de contrato, mencionadas na "Introdução" (:149), houve um investimento de peso na análise das etnografias do início do século, o que é evidenciado pelos escritos e registros de cursos, anteriores ao ED. Resenhista incansável, como o atesta sua vasta contribuição ao Année Sociologique ${ }^{4}$, M auss detinha um notável controle do que estava sendo produzido àquela época nos Estados Unidos, na Inglaterra e na Alemanha ${ }^{5}$ e utilizava textos e reflexões a respeito para suas atividades didáticas. $O$ exame destes materiais permite melhor compreender o plano do ED.

Foi pelo alerta de Emile Durkheim (M auss 1979[1930]:216), tio materno e tutor intelectual, que M auss tomou conhecimento dos primeiros 
trabalhos de Boas sobre os kwakiult (N oroeste americano). No ano letivo de 1905-6, a nomenclatura e as características dos principais tipos de família entre povos do Noroeste americano constituem o tema do curso que oferece na Ecole Pratique des Hautes Etudes. $\mathrm{Na}$ ementa consta que a instituição do potlatch, encontrada naquela região, foi submetida a um estudo comparativo e aprofundado "pois ela afeta e domina todos os fenômenos sociais das tribos" (1969:58). No curso de 1910-11, M auss visou a explicação de documentos referentes às prestações religiosas, jurídicas e econômicas entre clãs, nas tribos do Noroeste americano (:59). Ainda em 1910, em resenha a trabal hos de Swanton, persiste no estudo do potlatch. Naquela época achava que esta instituição constituía um sincretismo único de fatos sociais na história da Humanidade (:77). No curso de 1911-12, a instituição continua sendo seu tema: M auss então desenvolve "uma teoria do notável potlatch" (:60). Em 1913 publica uma resenha do trabalho de Boas, datado de 1909, "The Kwakiutl of Vancouver Islands" (Fournier 1994:799).

Os fatos referentes à M elanésia, que seriam incorporados ao ED, parece terem chegado ao conhecimento de M auss por meio de Seligman, Nehuhauss e Williamson, cujos livros sobre a Nova Guiné, datados, respectivamente, de 1910, 1911 e 1912, são objetos de resenha em 1913. Nos fatos descritos pelos autores, Mauss identifica elementos que o levam a concluir que o potlatch não se restringe ao N oroeste americano:

“[...] é, portanto, de forma definitiva, esta instituição que estes diferentes trabalhos mel hor iluminam. Não é mais possível ver nela uma curiosidade etnográfica do Noroeste americano: está claro que ela [a instituição] se deve a causas gerais e profundas [...]. É uma forma de contrato primitivo, cuja freqüência será constada cada vez mais, à medida em que se amplie o estudo do sistema de trocas nas sociedades inferiores" (M auss 1969:34).

No ano letivo de 1912-13, é a comparação entre os fatos do Noroeste americano e da Nova Guiné que constitui objeto de seus ensinamentos. A pós o interregno da guerra de 1914-18, M auss prossegue na reflexão a respeito da extensão do potlatch na M elanésia. Em uma comunicação ao Institut Français d'Ethnologie (:29-31), em 1920, ele faz uma espécie de balanço do avanço e estado de suas análises. Naquele momento, considerava a instituição do potlatch parte do que denominava de "sistema de prestações totais", próprio às sociedades de base clânica. Dentre estas prestações, destacava a troca de mulheres, de direitos, de coisas, de ritos religiosos que se faziam entre clãs, e chamava a atenção para o caráter suntuário e usurário dos empréstimos, e, ainda, para a dimensão agonís- 
tica da oposição entre grupos. Dizia ele, então, aos colegas que, já antes da guerra, após ter colocado em relação elementos esparsos, como festas, instituições jurídicas e rituais de confrarias, havia sido possível identificar a instituição do potlatch na M elanésia Ocidental. O material contido nos trabalhos sobre as IIhas Salomão, do etnólogo vienense Richard Thurnwald, havia também permitido que ele identificasse um sistema de prestações em Buin e o levado a rever o material da M elanésia. Desta revisão concluía a existência não apenas de traços importantes do potlatch como de formas agonísticas na M elanésia Oriental e Central. Continuou a desenvolver estas preocupações em suas atividades didáticas: as instituições do tipo potlatch na Melanésia foram o tema dos cursos de 1920-21 e 1921-22 e o livro de Rivers, History of M elanesian Society, o texto explorado com os alunos.

Um trabalho de 1921, "Une Forme Ancienne de Contrat Chez les Thraces" (1969:35-43), permite perceber que àquela data Mauss já havia logrado relacionar as formas de contrato e troca sobre as quais vinha trabalhando, a partir do Noroeste americano e da M elanésia, com o mundo indo-europeu. N essa publicação, que se inicia com uma síntese a respeito do estado de suas reflexões acerca do "sistema de prestações totais", M auss caracteriza o potlatch a partir de dois traços: as trocas, que implicam uma enorme quantidade de prestações de todo o tipo, começam sob a forma de doações aparentemente gratuitas de presentes, cujo beneficiário será obrigado a retribuir o equivalente com usura; e o caráter agonístico, mais acentuado no N oroeste americano do que na M elanésia. Lá os chefes se enfrentam mais do que se ligam, numa rivalidade constante, sendo por este meio que se fixa a hierarquia das famílias e dos clãs (:36). Contava ele que todas as tentativas para encontrar no mundo indo-europeu fatos semelhantes haviam sido infrutíferas, até que, por acaso, teria encontrado em textos gregos a prova de que populações consideráveis do Norte da Grécia Antiga, como os Trácios, haviam conhecido instituições do mesmo gênero, i.e., "sistemas de prestações totais com o primeiro traço do sistema evoluído do 'potlatch': dons com recuperação usurária no sentido moderno do termo" (:37). A pós construir sua demonstração, M auss termina o texto anunciando uma espécie de plano de trabalho. Diz ele que seria interessante encontrar entre outros povos antigos - e cita especificamente os celtas e os germânicos - evidências do mesmo tipo, que permitissem a verificacão de como aquelas formas haviam se "degradado" num simples contrato de troca (:43).

Nessa mesma época M auss ocupava-se da edição dos trabalhos de colegas do grupo do Année Sociologique, mortos durante a guerra, em 
especial os de Robert Hertz. Em 1922 edita na Revue de I'Histoire des Réligions, o texto "Le Péché et l'Expiation dans les Sociétés Primitives" (Hertz 1988[1922]), com introdução e conclusão de sua autoria. Foi remexendo nos escritos e notas do colega que Mauss encontrou materiais da Polinésia, particularmente referentes aos maori, que se ajustavam às suas preocupações de então a respeito das prestações totais. No ano seguinte à edição do texto ele faz uma comunicação, no Institut Français de I'A nthropologie (M auss 1969:44-45), sobre a obrigação de retribuir os presentes, na qual assinala o interesse que apresentam alguns temas do direito polinésio e, em particular, maori. Diz então que, se os polinésios não possuíam uma instituição que mereça o nome de potlatch, como no Noroeste americano e na M elanésia, el es conheceram formas de prestações totais. O tema da rivalidade e do combate estava ausente, mas o tema do presente obrigatório e voluntariamente dado e recebido era ali essencial (:44). Naquele momento, via no estudo das prestações totais na Nova Zelândia a possibilidade de explicar "um dos três elementos deste sistema de direito, que consiste na troca permanente de presentes. Pois este sistema supõe: 1 . a obrigação de dar; 2 . a obrigação de receber; 3 . a obrigação de retribuir" (:44-45). M auss atribui importância à formulação de "um jurista maori, Tamati Ranapiri" (:44), que havia sido anotada por Hertz, segundo a qual os objetos taonga eram dotados de hau, i.e., de espíritos, e que era impulsionado pelo hau do presente que o destinatário estava obrigado a devolvê-lo ao primeiro doador (:44). M auss concluía a comunicação anunciando que temas equivalentes de direito eram encontrados nos países com potlatch na M elanésia, na Nova Caledônia e no Noroeste americano, e que também poderiam ser indicados para o direito germânico e talvez para o direito romano muito antigo (:45).

M auss parece ter encontrado a última peça do quebra-cabeças dos "sistemas de prestações totais" nos Argonautas do Pacífico Ocidental, que Malinowski publicou em 1922 (1961[1922]). No ano letivo de 192324, M auss trabal ha acerca dos "documentos de Malinowski sobre as Ilhas Trobriandesas, na M elanésia". Neles, Mauss reconhece instituições que, estando mais particularmente ligadas à religião, à estrutura jurídica e ao regime econômico, são do tipo do "potlatch propriamente dito", e dedica particular atenção à noção de dom, de desinteresse e garantia. No final do relatório do curso, é anunciado que um resumo daquele ensinamento seria publicado em breve no Année Sociologique (M auss 1969:61). Tratava-se, certamente, do que viria a ser o próprio ED.

No balanço do estado de suas pesquisas com Davy, que encerra a "Introdução" ao ED, M auss apresenta os resultados a que tinha chegado. 
Ressal ta que nas economias e direitos que precederam os "nossos" não existe uma troca simples de bens, riquezas e produtos entre indivíduos: são as coletividades (pessoas morais) que obrigam mutuamente e trocam entre si; elas trocam não apenas bens móveis e imóveis, mas sobretudo gestos de polidez, festas, ritos, mulheres, criancas etc.; as prestações e contra-prestações são feitas de forma voluntária sob a forma de presentes, embora sejam obrigatórias. M auss distingue, então, no âmbito dos sistemas de prestações totais, o potlatch, que se caracterizaria pelo seu caráter agonístico evidenciado pela rivalidade e antagonismo que dominam todas as práticas. Conclui esta parte anunciando: “Diversos temas - regras e idéias - estão contidos neste tipo de direito e economia. $O$ mais importante, dentre estes mecanismos espirituais, é evidentemente aquele que obriga a retribuir o presente recebido". Assinala, ainda, que é na Polinésia que a razão moral e religiosa desta coerção se apresenta de forma mais evidente. Dito isto, $M$ auss passa a desenvolver seus argumentos, imprimindo, no entanto, uma ordem na exposição quase que inversa ao percurso que havia trilhado anteriormente.

No capítulo I, toma o caso da Polinésia como um exemplo de prestação total, e examina a obrigação de retribuir no âmbito da teoria do direito e da religião maori (:157). É neste contexto que faz referência a Hertz e às suas notas sobre o hau, que na concepção maori seria o espírito do doador. M auss trata o hau como uma idéia central do direito maori (:159) e a partir desta descoberta, extrai duas conclusões. Primei ramente, que os fatos examinados permitem perceber a natureza do elo jurídico criado pela transmissão de uma coisa e podem vir a esclarecer a elaboração de uma "teoria geral de obrigações". O direito maori é o que o leva a concluir que o laço de direito, o laço pelas coisas, é um laço de almas (:160). Em segundo lugar, M auss mostra que nesses sistemas de idéias compreende-se mais claramente que é preciso retribuir o que constitui parcela de sua natureza e substância. Segue-se o exame das duas outras obrigações: a de dar e a de receber. Mauss destaca, sempre referido à Polinésia, que os homens não são livres para não dar e não receber.

No capítulo II, intitulado "Extensão do Sistema: Liberalidade, Honra e Dinheiro", o mais longo do ED, M auss dedica-se à análise do potlatch. Começa com uma breve referência às regras de generosidade nas IIhas Adamanesas, entre os pigmeus estudados por Radcliffe-Brown, que lhe permite identificar traços do potlatch indo-europeu (objeto do capítulo III) e a "ampla difusão de um tema de direito" (:172). Em seguida, detémse nos fatos da M elanésia - "Princípios, Razões e Intensidade da Troca de Dons" (:174-194) - que lhe abrem o caminho para mostrar, melhor do 
que a partir da Polinésia, o sistema de dons e a troca do potlatch. Centra a atenção nas IIhas Trobriandesas e no kula, as trocas de colares e braceletes entre parceiros fixos, descritas e analisadas por M alinowski (1961 [1922]). O capítulo se encerra com a análise do potlatch no Noroeste americano, que, como se viu, havia sido o ponto de partida da reflexão de M auss. Formula então a hipótese de que o princípio da troca-dom deve ter sido aquele que prevaleceu nas sociedades que superaram a fase da "prestação total" e que ainda não alcançaram o contrato indidivual puro no qual circula o dinheiro (:227).

No capítulo III, "Sobrevivências destes Princípios nos Direitos e Economias Antigas", M auss postula que as instituições até ali analisadas teriam um valor sociológico geral e de história social, pois foram instituições deste tipo que forneceram a transição para os "nossos" direitos e economias. Para fundar seu argumento, chama a atenção para o fato de que vivemos em sociedades que distinguem os direitos reais dos direitos pessoais, as pessoas das coisas. Esta separação é a condição mesma da existência do "nosso" sistema de propriedade, de alienação e de troca. Ora, tal distinção, prossegue o autor, inexiste no direito da Polinésia, da M elanésia e do Noroeste americano, que acabara de examinar. Por outro lado, "nossas" civilizações distinguem a obrigação e a prestação não gratuita do dom. Pergunta-se, então, se esta distinção não seria recente no direito das grandes civilizações, se elas não teriam praticado uma troca de dons em que as pessoas se misturam com as coisas. É neste contexto que passa ao exame de traços dos direitos indo-europeus. Roma, Índia e Germânia irão Ihe fornecer as provas para seus argumentos.

Nas Conclusões, M auss dedica a primeira parte a considerações de ordem moral. A pós destacar a permanência do dom, da liberdade e da obrigação em "nossas" sociedades, faz a defesa - claramente uma intervenção nos debates da época - da incorporação da moral do dom ao "nosso" direito. Na segunda conclusão, M auss examina as implicações dos fatos examinados para a análise de fatos econômicos mais gerais. Trata-se de colocar em questão, assim como o fez Malinowski, as doutrinas correntes a respeito da economia natural (:266) e de ir mais adiante: dissolver e dar outra definição às noções que ele próprio utilizou, como dom e presente, pois as considera inexatas; bem como rever os conceitos do direito e da economia que são freqüentemente opostos, tais como liberdade e obrigação, liberalidade, generosidade, luxo e poupança, interesse e utilidade (:267). A poiando-se novamente no caso analisado por Malinowski, procura indicar que necessitamos de noções mais complexas, pois o que está em jogo não é nem uma prestação puramente livre e gra- 
tuita, nem a produção e a troca puramente interessada na coisa útil. É uma espécie de híbrido que prevalece entre os trobriandeses. M auss termina o ensaio com observações de método e fixando os limites de sua empreitada. Diz ele que não estava propondo um modelo: o trabalho era indicativo e estava incompleto; o que visava era a formulação de questões para historiadores e etnógrafos, assim como a sugestão de objetos de pesquisa; não pretendia nem resolver um problema, nem fornecer uma resposta definitiva. Quis ele, no entanto, destacar, naquele final, o princípio de método que usara para abordar os problemas. Lidou, ressalta, com "fatos sociais totais", isto é, com fatos que colocam em marcha, em alguns casos, a totalidade da sociedade e de suas instituições (potlatch, clãs que se afrontam, tribos que se visitam) e, em outros, somente um grande número de instituições, quando as trocas e os contratos dizem respeito aos indivíduos (:274). Os fenômenos, prossegue ele, são ao mesmo tempo jurídicos, econômicos, religiosos, estéticos e morfológicos. M ais do que temas, elementos de instituições, como religião, economia, direito etc., são "todos", sistemas sociais inteiros, cujo funcionamento tentou descrever, em seu estado dinâmico, e não como se estivessem petrificados, a serem decompostos e dissecados em regras.

\section{Um capítulo em uma obra}

O ED teve uma acolhida favorável: M alinowski, em sua já mencionada carta a M auss, afirmava que lera com grande interesse seu "admirável artigo" (Fournier 1994:524); também Boas escreveu ao autor para Ihe dizer que considerava o trabalho um "investigação interessante" (:524); e Henry Lévy-Bruhl não poupou elogios ao colega em sua resenha. As críticas vieram da parte de Henri Hubert. O grande amigo e colaborador confessou a M auss, em carta, que a expressão "prestações totais" não Ihe convencia: "mesmo ali onde seu comentário parece convir à expressão, há sempre alguma coisa que escapa à totalidade da prestação". Hubert também o advertia em relação à primeira parte do trabalho: "não se engane porque ela não é fácil de ler; há no comentário dos fatos um fluxo de palavras que não são nem generalizações formais, nem definições precisas. M uitas vezes é bastante nebuloso". Criticava ainda o fato de ter misturado na análise "considerações de política e de moral prática" (referindo-se certamente à primeira conclusão) e fazia algumas retificações a respeito do que M auss escreveu acerca do direito germânico, incitando-o a incluir o direito feudal na análise (Fournier 1994:524-25). 
Em 1926, em Londres, Malinowski publica o livro que anunciara a M auss, Crime and Custom in Savage Society (1970[1926]), cujo tema é o direito e a ordem nas sociedades ditas primitivas. O problema, como o constrói, é saber por que o primitivo obedece a regras de conduta muitas vezes duras e desagradáveis, por que a vida privada, a cooperação econômica e os acontecimentos públicos desenrolam-se a contento, em suma, em que consistem as forças do direito e da ordem (:9). Sua preocupação parece inscrever-se na mesma ordem de questões formuladas por M auss, que se perguntava, na abertura do ED, pela regra de direito que explicava uma determinada conduta (a retribuição do presente). Mas M alinowski não estava se dirigindo ao colega francês, cujo texto provavelmente desconhecia por ocasião da redação do livro, mas sim a interlocutores como E. Sidney Hartland, Rivers e Lowie, nos quais criticava o fato de não terem percebido que a obediência a regras nada tem de espontâneo. Todo seu esforço será dirigido no sentido de mostrar que as normas de conduta impõem obrigações entre os indivíduos e de colocar em evidência o que garante o cumprimento destas obrigações na ausência de um aparel ho de coerção. A poiando-se no material etnográfico coletado nas Ilhas Trobriandesas, ele destaca que as relações de dependência, como aquelas que vinculam os habitantes da costa aos do interior, são, por si só, uma garantia para que se desincumbam das obrigações de trocar produtos. E é como dependência que Malinowski concebe a noção de reciprocidade. Interessados ainda no prestígio auferido por meio de condutas generosas (porque ali a generosidade é um valor), os trobriandeses, acrescenta o autor, cumprem suas obrigações movidos também por ambições pessoais, dentre elas, a vaidade.

Ao longo do texto, há uma única referência ao ED, em nota provavelmente acrescentada no prelo. Malinowski (1970[1926]:41) reconhece a justeza da crítica de que não existem dons livres, como afirmara anteriormente haver entre o marido e a mulher (Malinowski 1961[1922]:177180), e atribui o erro ao fato de ter isolado uma categoria de presentes das demais, de tê-la descontextualizado. A abordagem adequada, corrige-se, consiste em examinar todo o sistema de dons, deveres e beneficíos mútuos trocados entre o marido e a mulher, os filhos e o irmão da mulher. Talvez porque estivesse sintonizado com as mesmas inquietações de M auss, Malinowski acaba "respondendo", sem que isso tenha sido intencional, à outra crítica que Ihe havia sido dirigida no ED: o fato de não ter descrito, ao lado do comércio do kula, outras instituições nas quais os mesmos princípios seriam aplicados (M auss 1991[1923-24]:175). Em Crime and Custom, ele apresenta os mecanismos que atuam em outras for- 
mas de comércio. Ficou, no entanto, devendo a M auss a explicitação da sanção aos que falhavam no kula (:184-185).

A primeira crítica ao ED que logrei localizar data de 1929. Ela figura em um capítulo do livro de Raymond Firth (1959[1929]) sobre economia dos maori, sua tese de doutorado orientada por Malinowski e elaborada a partir de documentos, pois não havia feito campo na Polinésia6. No capítulo 12, "A Troca de Presentes" (:393-432), o autor questiona a interpretação de $M$ auss a respeito do hau, interpondo o argumento de que o conceito maori não designaria o espírito do doador, mas o do bem doado (:421); e afirma que a sanção mágica, destacada no texto de 1924-25, não é a única que garante a retribuição do presente, pois há também o medo de perder futuras oportunidades de troca e a própria reputação, sanções que M auss havia assinalado para outras províncias etnográficas, mas não para os maori (:421). É provável que, no que se refere a esta segunda ponderação, Firth tenha sido estimulado pelo orientador a se valer do material maori para apontar uma fragilidade do ED no que diz respeito às sanções ao não cumprimento das obrigações. Para justificar a atenção que dispensa à crítica da interpretação dos fatos da Polinésia, Firth acaba, no entanto, incorrendo em algumas impropriedades: superestima a importância das evidências maoris (:418) no plano do ensaio, e ainda assegura serem estas centrais para a "teoria geral" da reciprocidade do ED. Ora, como foi visto, $M$ auss em nenhum momento afirma estar elaborando uma tal teoria. A única que menciona é a "teoria completa destas três obrigações" (dar, receber e retribuir) e tem a precaução de deixar claro que naquele momento só poderia fornecer indicações (M auss 1991[1923-24]: 161). Por outro lado, o vocábulo reciprocidade sequer faz parte do léxico do artigo do Année Sociologique: há referência apenas a dons recípro$\cos$, o que não corresponde ao conceito de reciprocidade.

A crítica parece não ter suscitado uma resposta de M auss. Ao menos, não localizei nenhuma referência em seus trabal hos, nem em nenhum outro autor. Talvez isso se deva ao abandono do tema, pois após a publicação de 1924-25, não voltou a abordá-lo, senão de forma esporádica7. As prestações totais e as prestações totais agonísticas, do tipo potlatch, haviam detido a sua atenção no âmbito do estudo sobre instituições, e estas eram secundárias em relação a seu interesse principal: os rituais e as representações religiosas. É o que se constata no memorial que escreveu, certamente em 1930, quando de sua candidatura ao Collège de France (M auss 1979[1930]:146-8). Na concepção que tinha então de sua obra, o ED, assim como o "Ensaio sobre as Variações Sazonais das Sociedades Esquimós" (M auss 1991[1904-5]), era visto como uma contribuição no 
sentido de acrescentar a concepções anteriores, "corretas mas parciais", aquela de uma estrutura de "repartição de direitos e deveres entre grupos". A chava ele ainda que os problemas, como os examinou, superavam e desl ocavam maneiras de formular as questões e permitiam "antever soluções para questões gerais e mesmo morais" (:216-217). O texto de 1924-25 não ocupava, para Mauss, o lugar central que vieram depois a Ihe atribuir os antropólogos.

\section{Rumo à reciprocidade}

Nos anos 30 e 40, o ED e outros trabalhos de M arcel M auss, escritos em colaboração com Hubert, sobre religião e magia, circulavam e eram discutidos na Inglaterra e nos Estados Unidos, que abrigavam então os principais centros de ensino e pesquisa em antropologia.

$\mathrm{Na}$ London School of Economics, onde Malinowski empreendera a consolidação da antropologia social como disciplina, tanto ele quanto Firth (então incorporado ao staff), bem como M eyer Fortes e M argaret Read, incluíam habitualmente textos daqueles autores em cursos nas áreas de teoria geral e religião e economia primitiva8. Hubert e M auss figuravam também na lista dos mais lidos nos seminários de M alinowski, como o atestaria Raymond Firth (1975:2), o principal colaborador do fundador da antropologia social britânica e, na década de 40, seu sucessor. $\mathrm{Na}$ Universidade de Chicago, artigos de M auss e Formas Elementares da Vida Religiosa, de Durkheim, eram leitura obrigatória dos estudantes, como confidenciava a M auss seu ex-aluno M étraux, que lá estivera, em carta datada de 1938 (Fournier 1994:634-635). Um ano antes, também em carta, contava-Ihe entusiasmado que sua influência talvez fosse maior nos Estados Unidos do que na França.

O antropólogo Robert Lowie, uma das principais figuras da antropologia norte-americana da época e desde 1925 professor na Universidade de Berkeley (M urphy 1972:325), parecia compartilhar o apreço que os colegas de Londres tinham por M auss e Hubert. Tanto é que na história do pensamento antropológico, publicado em 1937, reservou-Ihes um lugar de destaque no capítulo dedicado à sociologia francesa: foram os únicos colaboradores de Durkheim a merecer um comentário em separado (Lowie 1971[1937]:193-196). De seus textos, selecionou dois que já faziam sucesso em Londres - o texto sobre a magia e o ED - e o estudo de M auss sobre os esquimós. O ED, cuja contribuição ao estudo da hierarquia ele já havia ressaltado anteriormente (Lowie 1969[1936]:321), é 
apresentado como um caso exemplar de realização da metodologia durkheimeana. N ele, M auss explorava fatos típicos e bem documentados em vez de de estender a comparação valendo-se de fatos dispersos e isolados. Lowie retém do trabal ho as análises de M auss a respeito do caráter obrigatório do dar e receber, o conceito de prestações totais para descrever as trocas entre grupos e as formas como as trocas se dão na Polinésia, $M$ elanésia e N oroeste americano. Encerra a sua breve referência ao texto, elevando M auss à condição de um maiores especialistas em economia primitiva, como Malinowski e Thurnwald, e destacando a conclusão metodológica do ED, notadamente aquela que diz respeito aos aspectos sociais, religiosos e estéticos dos fatos econômicos. Embora tal imbricação já houvesse sido destacada por outros, Lowie via no texto de M auss uma demonstração vigorosa a partir de exemplos concretos e a tal virtude atribuía o fato desta "preciosa contribuição" ter recebido uma acolhida mais favorável do que a maioria dos trabal hos da "escola" de Durkheim.

Para os autores que escreveram na década de 30, tratando de fatos relativos à troca, o ED não figura como uma referência explícita. M alinowski, por exemplo, em seu Coral Gardens (1935), dedica o quarto capítulo ("The Customary Law of Harvest Gifts") ao exame das razões que levariam nas II has Trobriandesas um homem a oferecer a mel hor parte de sua colheita ao irmão de sua mulher (:188-217) e busca as respostas em um sistema complexo de regras econômicas, legais e sociológicas, como já o havia feito em Crime and Custom, um pouco na mesma direção que M auss. Não cita o ED, mas a inspiração é clara, tanto no plano das questões - a força que propulsiona para dar e as sanções ao não cumprimento das obrigações - quanto no uso do conceito de prestação, caro ao autor do ensaio em toda a sua argumentação. Também a M auss não se refere Richard Thurnwald, ao se interrogar, em 1936, sobre o fenômeno da troca, como o assinala J uillerat (1993:2). N este caso, a ausência de referência é coerente com uma falta de sintonia que parece ter escapado ao comentador. Thurnwald formulava questões estranhas às preocupações de M auss. A ele interessava explicar a "origem da reciprocidade", percebida como relações simétricas, enquanto para o autor do ED o que importava era identificar a regra de direito e de interesse que faz com que o presente recebido seja obrigatoriamente retribuído. A busca da resposta em mecanismos biopsíquicos (:22) haveria certamente de receber de M auss, caso tivesse dado seguimento à investigação sobre o tema, críticas semelhantes às de Malinowski, que, comentando trabal hos anteriores de Thurnwald, lamentava que este não tivesse reconhecido os 
aspectos legais da simetria, tampouco suas funções de salvaguarda da continuidade de serviços mútuos (M alinowski 1970[1926]:24).

\section{A "obra-prima" de um profeta}

$\mathrm{N}$ a segunda metade da década de 40, o ED haveria de ser destacado como uma descoberta da "idéia fundamental da reciprocidade", no balanço que o etnólogo Claude Lévi-Strauss fez então da sociologia francesa no século XX (1965[1946]:20).

No final da década, quando M arcel M auss já se encontrava doente e afastado das atividades intelectuais ${ }^{9}$, seu ED foi invocado pelo mesmo autor, como um trabalho "admirável", "clássico" e fonte de inspiração para a explicação das trocas matrimoniais por meio do que ele denominava de "princípio de reciprocidade". Esta referência está inscrita no livro Les Structures Elémentaires de la Parenté (1967[1949]:61), originalmente a tese de doutorado de Lévi-Strauss, elaborada a partir de pesquisa em bibliotecas norte-americanas e defendida em 1948 em Paris. O trabalho tinha a ambição de formular uma teoria geral dos sistemas de parentesco e adotava como método, segundo o autor, uma espécie de combinação do procedimento de examinar exemplos extraídos de diferentes contextos, como o havia feito Frazer, com o de se limitar ao estudo dos fatos no seu próprio contexto, ao estilo de Durkheim. Também quanto a esta escolha metodológica, o autor reivindicava uma inspiração mausseana (:XI-XII).

Lévi-Strauss inicia o capítulo V, "O Princípio de Reciprocidade”, com o que seriam as conclusões do ED:

“[...] a troca se apresenta, nas sociedades primitivas, menos sob a forma de transações que de dons recíprocos; [...] os dons recíprocos ocupam um lugar muito mais importante nessas sociedades do que nas nossas; [...] esta forma primitiva de trocas não tem apenas, e nem essencialmente, um caráter econômico, mas coloca-nos diante do que ele [M auss] numa feliz expressão denomina 'um fato social total'” (1967[1949]:61).

M enciona, ainda no mesmo parágrafo de abertura, sociedades em que tais fenômenos ocorreriam e se detém no exemplo da Polinésia, nos maori, referindo-se a Best (a fonte de Hertz) e ao livro de 1929 de Raymond Firth, mas não à crítica deste a M auss (:61). Ao longo do capítulo, o autor formula a tese de que os fenômenos da troca se inscrevem em um 
mesmo complexo fundamental da cultura. Mais adiante, no capítulo VII, desenvolve a teoria de que a origem desses fenômenos, assim como da proibição do incesto, das regras de exogamia e das organizações dual istas, residiria nas “estruturas fundamentais do espírito humano" , cuja universalidade reivindica. Tais estruturas seriam a exigência da regra como regra, a noção de reciprocidade e o caráter sintético do dom (:98).

M auss morre em 1950. Para homenageá-lo, o sociólogo francês Georges Gurvitch organiza uma coletânea de textos seus, na qual figurava o ED, e convida Lévi-Strauss para escrever a introdução. Esta era a segunda vez que Ihe confiava um trabalho: o primeiro havia sido o capítulo referente à sociologia francesa, no volume dedicado à sociologia no sécuIo XX (Gurvitch e M oore 1965[1946]). Os dois conheciam-se desde N ova Iorque. Lá haviam se refugiado durante a Segunda Guerra M undial e atuado como professores da Escola Livre de Altos Estudos (Lévi-Strauss e Eribon 1988:102). Em 1950, ambos reivindicavam a herança mausseana e estavam empenhados em reabilitar, via Mauss, a Escola Sociólogica francesa no ambiente hostil ao durkheimeanismo do pós-guerra na França10. Em vida, M auss não havia publicado nenhum livro e seus trabalhos encontravam-se dispersos em periódicos, notadamente no Année Sociologique. A coletânea inscrevia-se em um projeto de editar suas obras completas ${ }^{11}$.

Lévi-Strauss inicia a "Introdução" a Sociologie et Anthropologie (Lévi-Strauss 1991[1950]) com um elogio a Mauss: diz que poucos pensadores tiveram tamanha repercussão na França e refere-se aos "ecos duráveis" que sua obra teria alcançado no exterior, junto a figuras como Malinowski, Radcliffe-Brown, Firth, Evans-Pritchard, na Inglaterra, e Redfield, Herskowitz e Lloyd Warner, nos Estados Unidos. Na França, sua influência havia se produzido mais pela via do contato regular ou ocasional com colegas e discípulos, e, fora dela, através do "acaso de um encontro ou uma leitura" (:IX) do que diretamente por seus escritos. Isto posto, LéviStrauss institui o contato pessoal como critério para legitimar a pretensão a intérprete autorizado: só os que o conheceram e o escutaram - e implicitamente ele se considera um deles 12 - estão em condições de avaliar a fecundidade da obra e dela fazer um balanço. Em seguida dá início a seus comentários.

O pensamento de Mauss é caracterizado como "denso" e "esotérico" , "pontilhado de luzes" e dado a procedimentos às vezes "tortuosos" que o afastavam do caminho que o conduziria ao "coração dos problemas". Lévi-Strauss anuncia sua intenção de destacar na obra alguns "aspectos" e norteia-se, ainda que não de modo explícito, pela preocu- 
pação de colocar em evidência o que lhe parece constituir o caráter precursor dos escritos de M auss, desde as primeiras páginas apresentado como uma espécie de profeta, que teria se antecipado a uma série de desenvolvimentos ulteriores da antropologia.

Dentre o conjunto de seis textos reunidos na primeira edição de Sociologie et Anthropologie13, Lévi-Strauss detém-se mais longamente no ED: dedica-Ihe 16 das 43 páginas da "Introdução". O trabal ho é apresentado como um texto "capital", o "mais justamente célebre, aquele cuja influência foi mais profunda" (:XXIV), um acontecimento decisivo da "evolução científica" (:XXXIII), uma "obra-prima". Tantas honrarias o $E D$, em sua saga desde os anos 20 , jamais havia recebido. Lévi-Strauss valorizava particularmente este trabal ho de M auss, como Ihe confessara em longa carta datada de outubro de 1944 e escrita em N ova Iorque: o artigo de 1923-24 era sua fonte de inspiração e ponto de partida para as análises sobre as trocas matrimoniais (Fournier 1994:735). A final, era esse o texto do mestre que mais se prestava ao estabelecimento de uma conexão com o rumo que dava às suas investigações.

A noção de "fato social total" é o primeiro "aspecto" que LéviStrauss destaca do artigo. A partir de algumas poucas citações do texto, incluídas sem referência nem às páginas, nem ao contexto, ele apresenta sua versão do "fato social total", como se estivesse apenas expondo o pensamento de $M$ auss e apontando suas implicações. Não se trata aqui de confrontar a representação lévi-strausseana do "fato social total" com o uso que faz M auss da noção no corpo de seu artigo, mas tão-somente destacar que é graças à ausência de citações, que Lévi-Strauss logra estabelecer afinidades entre o que seria o "fato social total" e conceitos ou problemas com os quais vinha trabalhando, notadamente os de sistema, inconsciente e a oposição observador-observado. $\mathrm{O}$ que em M auss aparecia como um recurso de método (tratar como "fatos sociais totais") e sempre no plural, em Lévi-Strauss torna-se um conceito a designar uma totalidade, no singular.

O outro "aspecto" do ED a ser explorado e que se configura como o mais importante para o apresentador é a "revolução" que M auss teria operado. Diz Lévi-Strauss: “pela primeira vez na história do pensamento etnológico um esforço foi feito para transcender a observação empírica e ascender às realidades mais profundas" (:XXXIII). A "descoberta" atribuída ao autor passa então a ser louvada: ela teria aberto novas possibilidades metodológicas, como aquelas exploradas por Firth com a análise dos "ciclos de reciprocidade" entre os tikopia; estaria próxima das descobertas, também metodológicas, feitas por Troubetzskoy e J akobson no 
que se refere à lingüística estrutural; sua relevância seria equivalente à da descoberta da fonologia para a lingüística; o texto teria, enfim, inaugurado uma "nova era para as ciências sociais" (:XXXV), e sua importância seria comparável àquela da descoberta da análise combinatória para a matemática moderna. Mas, para a "infelicidade" da etnologia (:XXXV), M auss não explorou sua própria descoberta. Sua intuição, no entanto, estava certa, assevera Lévi-Strauss. Como prova apresenta outra descoberta, mais recente no domínio do parentesco, de "regras precisas, segundo as quais se formam, em qualquer tipo de sociedade, ciclos de reciprocidade cujas leis mecânicas são conhecidas, permitindo assim o emprego do raciocínio dedutivo num domínio que parecia submetido ao arbitrário" (:XXXVI). Não há uma autocitação, mas não é difícil reconhecer nessa passagem a teoria desenvolvida pelo autor em 1949. A ssim, a justeza da reflexão de Mauss estaria no desenvolvimento que ele, o comentador, teria dado ao seu achado.

É então que Lévi-Strauss oferece uma explicação para o fato de M auss não ter explorado sua própria descoberta, e o compara ao profeta M oisés que não logrou “conduzir seu povo à terra prometida” (:XXXVII). $M$ auss teria a certeza lógica de que a troca é um denominador comum de grande número de atividades humanas. A observação empírica não Ihe permitia ver a troca nos fatos, mas tão-somente as obrigações de dar, receber e retribuir. A “teoria”, afirma Lévi-Strauss, exigia uma estrutura. Não fica claro de que teoria se trata, nem é possível localizar no ED uma preocupação desta natureza. A solução encontrada por Mauss para o problema que Ihe atribui o comentador foi aplicar uma "fonte de energia que operasse a síntese". Segue-se então uma citação do ED: "Pode-se [...] provar que nas coisas trocadas [...] há uma virtude que força os dons circularem, serem dados e serem retribuídos" (:XXXVIII). O que é suprimido da citação, feita sem referência às páginas, permitiria ao leitor identificar o contexto original da formulação. Trata-se da conclusão da parte referente ao N oroeste americano, na qual Mauss analisa o potlatch. Eis a citação completa: “ pode-se ainda levar mais adiante a análise e provar que nas coisas trocadas no potlatch há uma virtude que força os dons a circularem, serem dados e serem retribuídos" (M auss 1991 [1923-24]:214; as ênfases correspondem às supressões). E prossegue Mauss: “Em primeiro lugar, os kwakiutl e os tsimshian fazem entre os diferentes tipos de propriedades a mesma distinção que os romanos ou os trobriadeses e os samoanos. Para eles [...]"(:214). 
Embora não esteja em jogo aqui fazer uma exegese do texto - tarefa para filósofos e hermeneutas - , não se pode concluir que M auss aí estivesse resolvendo o problema teórico formulado por Lévi-Strauss. Ele está apenas apresentando uma concepção nativa e relacionando-a com outras concepções nativas e com aquelas encontradas nos direitos antigos. Prosseguindo com o raciocínio do comentador: diz ele que, como a virtude da coisa não está na coisa, mas é concebida subjetivamente, ou bem esta virtude não é outra coisa senão o próprio ato da troca, ou bem ela é de uma natureza diferente e, em relação a ela, o ato da troca se torna um fenômeno secundário. O único modo de escapar ao "problema" teria sido perceber que é a troca que constitui o problema primitivo e não as operações discretas nas quais a vida social se decompõe. M auss teria procurado restituir o todo com suas partes, mas como isto seria impossível, teria então acrescentado uma quantidade suplementar. Esta quantidade seria o hau, o espírito da coisa, uma concepção dos sábios maoris:

“N ão estaríamos aqui diante de um desses casos (que não são assim tão raros) no qual o etnólogo se deixa mistificar pelo nativo? [...] O hau não é a razão última da troca: é a forma consciente sob a qual os homens de uma determinada sociedade, em que o problema tinha particular importância, conceberam uma necessidade inconsciente, cuja razão de ser está em outro lugar" (Lévi-Strauss 1967[1949]:XXXVIII-XXXIX).

Também aqui não há nenhuma citação do ED, nem menção ao contexto no qual M auss se refere ao hau e aos juristas maoris, tratados por Lévi-Strauss como "sábios". G raças a esta estratégia argumentativa, o hau, que aparecia em M auss como uma noção central do direito maori torna-se, com Lévi-Strauss, a explicação da troca. Foi este "equívoco" que impediu que M auss chegasse à terra prometida, tal qual ocorreu com M oisés. No caso, a terra prometida seria a percepção de que a realidade subjacente à troca só pode ser encontrada nas estruturas mentais inconscientes, que podem ser atingidas por meio das instituições e, sobretudo, da língua (:XXXIX).

\section{A mais-valia simbólica}

Claude Lévi-Strauss tinha 42 anos quando escreveu a "Introdução à Obra de Mauss". A pós uma estada quase ininterrupta de seis anos em $\mathrm{N}$ ova Iorque, havia regressado a Paris, em fins de 1947, disposto a iniciar uma 
carreira universitária. A té então, na França, só tinha sido professor do ensino secundário. Ele havia se iniciado no magistério superior durante sua estada no Brasil (1935-38), na então recém-criada Universidade de São Paulo, e, durante a guerra, voltado a lecionar nos Estados Unidos. Ainda quando lá estava não Ihe faltaram convites para trabalhar em prestigiosas universidades norte-americanas: recusou todos porque ambicionava exercer a profissão na França (Cohen-Solal 1999:25). Para um outsider autodidata, que vinha da filosofia, não tinha estudado etnologia e, apesar do campo feito no Brasil14, era visto como um antropólogo de gabinete, como o caracteriza Héritier (1999:63), havia todo um caminho a percorrer para inserir-se no establishment científico francês.

M auss, o grande nome da etnologia francesa, poderia, sem dúvida, tornar-se um apoio decisivo para o iniciante na disciplina. Em 1944, LéviStrauss Ihe escreve apresentando-se como fiel discípulo e pedindo-Ihe que aceite ser relator de sua tese de doutoramento (Fournier 1994:756 e 765). Em seus escritos de 46 e de 49, Lévi-Strauss homenageia M auss e não Ihe faz nenhuma crítica. Paralelamente, investe também em outra direção: empenha-se, a partir de N ova Iorque, em facilitar as negociações entre autoridades francesas e a Fundação Rockfeller com vistas à liberação de recursos para o desenvolvimento das ciências sociais na França (Cohen-Solal 1999:21-23).

De volta a Paris, Lévi-Strauss pede a Georges Davy, colaborador do mestre e então titular da cátedra de Sociologia na Sorbonne ${ }^{15}$, que se torne seu orientador, para que possa defender a tese que fizera nos Estados Unidos (Lévi-Strauss e Eribon 1988:76). Em 1948, é nomeado maître de recherche junto ao Centre National de la Recherche Scientifique (CNRS), "um posto de espera" (:80), e, em seguida, subdiretor do Musée de I'Homme. No ano seguinte, apoiado pelo historiador Lucien Febvre, que conhecera em 1935 quando estivera em missão na Universidade de São Paulo, passa a dar seminários na Ecole Pratique des Hautes Etudes (V seção). Candidata-se ao prestigioso Collège de France, mas não é aceito. Em 1950 apresenta-se novamente e volta a ter sua candidatura recusada16. Graças a Georges Dumézil, outro colaborador de Mauss, consegue ser indicado Diretor de Estudos da Ecole Pratique des Hautes Etudes, para a V seção, a de "Ciências Religiosas" e assume a cátedra "Religiões dos Povos Não Civilizados", que M auss ocupara entre 1901 e 1940.

Em pouco tempo, Lévi-Strauss logrou trilhar uma trajetória bemsucedida, com o apoio de pessoas próximas a M auss, que viam nele uma espécie de herdeiro "natural". Tal reconhecimento premiava seus esforços no sentido de associar seus trabal hos ao do mestre, especificamente 
ao ED. Tratava-se, no entanto, de uma associação mais retórica do que de fundo. J á em Les Structures Elementaires de la Parenté fica claro que seu ponto de vista era distinto, tanto no que se refere ao método - o valer-se de exemplos sem considerar o contexto etnográfico -, quanto no tratamento dado às trocas: uma manifestação de regras do inconsciente, do princípio de reciprocidade. Mas, se ser visto como o sucessor abriuIhe as portas do mundo universitário francês, conformar-se com o papel de reprodutor do capital herdado poderia barrar-Ihe um futuro mais proeminente, o qual certamente ambicionava, como o atestam as duas candidaturas a uma instituição de consagração como o Collège de France e o fato de que após a segunda derrota experimentou o sentimento de que sua carreira estava liquidada ${ }^{17}$. É possível supor que tenha, então, se dado conta de que, para ascender na hierarquia de prestígio, tivesse de agregar ao capital herdado uma espécie de mais-valia simbólica. É neste contexto que se pode entender o tratamento que dá à obra do mestre na "Introdução", particularmente ao ED. Lévi-Strauss consagra o texto, conferindo-Ihe um valor que até então não Ihe tinha sido atribuído, para em seguida apontar o "erro" que Ihe permitia fazer avançar sua própria teoria e aumentar o seu próprio valor ${ }^{18}$.

O fato de ter assim procedido certamente está relacionado com o modo de funcionamento do establishment científico francês: é provável que sua estratégia de distinção seja a apropriada naquele microcosmo, mas só uma pesquisa empírica que examinasse outros casos poderia avançar no entendimento da questão. Se tivesse optado por inserir-se no mundo acadêmico de outro país, Lévi-Strauss talvez pudesse ter desenvolvido sua própria teoria e dispensado as reverências a M auss e a busca de seus "erros". A comparação com o caso do antropológo britânico Edmund Leach pode ser neste sentido iluminadora. Como o colega francês, Leach ingressou tardiamente na carreira. Defendeu a tese de doutorado na London School of Economics, aos 36 anos, em 1946. No ano seguinte foi incorporado à equipe da mesma instituição como lecturer (a posição mais baixa na hierarquia universitária). Em 1951 publicou um ensaio com críticas devastadoras a Radclife-Brown, M eyer Fortes, EvansPritchard e a Lévi-Strauss (Leach 1951). Três anos mais tarde, lançou uma monografia sobre os kachins, na qual não se apoiava na teoria de nenhum colega, mas usava seu material para colocar por terra as idéias bem estabelecidas dos membros do establishment da antropologia social britânica (Leach 1996[1954]). Leach logrou ser reconhecido pelos pares, dentre eles pelos que havia criticado duramente, foi premiado pelo ensaio de 1951, tornou-se um dos grandes "nomes" 19 da antropologia social em seu 
país e durante toda a vida cultivou a representação de si mesmo como um "herético". Se a estratégia de confronto de Leach não Ihe barrou a ascensão na carreira, tal se deve, em grande parte, ao modo de funcionamento do establishment científico da Inglaterra, o qual certamente é distinto do francês ${ }^{20}$. Sobre ele não se abateram as mesmas coerções que levaram Lévi-Strauss a se apresentar como herdeiro de M auss para conseguir se tornar um "nome" na França.

\section{A difusão da dóxa}

A crítica de Lévi-Strauss a M auss não produziu efeitos imediatos. Salvo pelos comentários de filófosos como Claude Lefort (1951) e MerleauPonty (1960), não seria exagero dizer que permaneceu ignorada por algum tempo.

No volume do Année Sociologique de 1951, Henry Lévy-Bruhl escreve o In M emoriam a Marcel Mauss, cita a publicação do Sociologie et Anthropologie, mas não o texto de Lévi-Strauss. O ED é, então, mencionado, dentre outros textos "célebres" do autor, como um trabalho "admirável", que havia aberto importantes perspectivas sobre a gênese do direito e da economia política (Lévy-Bruhl 1951:3-4). No mesmo volume são publicados dois textos referidos a M auss e ao ED. Um é da autoria de Emile Benveniste, que destaca, logo na abertura, que o grande mérito de M auss em seu estudo sobre o dom foi ter demonstrado a relação funcional entre o dom e a troca, e definido, por meio desta relação, um conjunto de fenômenos religiosos, econômicos e políticos das sociedades arcaicas (Beveniste 1951:7). Ao longo do texto o lingüista segue a pista fornecida por M auss e procura explorar no vocabulário das línguas indo-européias elementos que iluminem a pré-história das noções de dom e troca (:8). O segundo texto, de Louis Gernet, é dedicado ao estudo dos direitos mediterrâneos da Antiguidade, notadamente das sociedades helenistas. Também aí trata-se de levar adiante pistas do ED e examinar representações religiosas e comportamentos nos quais seja possível buscar os antecedentes de um pensamento jurídico (1982[1951]:11-12).

Em 1952, por ocasião de conferência pronunciada em Oxford, onde se encontrava como professor visitante, o antropólogo francês Louis Dumont faz uma referência elogiosa à introdução de Lévi-Strauss, mas não meciona a crítica. Ressalta apenas a importância do texto para entender o impacto da obra de M auss sobre a antropologia contemporânea (1972[1952]:8). Dois anos mais tarde, Evans-Pritchard redige o prefácio à 
primeira tradução inglesa do ED. A introdução de Lévi-Strauss aí figura, ao lado do In Memoriam de Henry Lévy-Bruhl, como um exemplo de análise da contribuição de M auss ao pensamento sociológico na França. Também aqui nenhuma palavra sobre os equívocos contidos no ED. Ainda em 1954, J. P. J ohansen publica em Copenhagen um livro sobre os maori. O ED é citado como um texto que oferece reflexões finas e indiscutíveis a respeito da troca. $O$ autor, no entanto, faz duas ressalvas: a primeira diz respeito à tradução de um provérbio maori (1954:115; nota 75) e a segunda ao conceito de hau, que, segundo ele, apresentaria muito mais dificuldades do que M auss havia identificado (:117-119). Não há referência a Lévi-Strauss. Também nos anos 50, Edmund Leach (1955) faz a resenha da tradução do ED para o inglês. Como acompanhava de perto o trabalho de Lévi-Strauss, é pouco provável que desconhecesse a "Introdução". A ela, no entanto, não se refere, assim como também não o faz Paul Bohannan (1955) em estudo sobre a troca. Em meados da década de 60, Raymond Firth (1965[1939]) reedita outro livro seu sobre economia primitiva, em que comenta o ED: destaca a contribuição de M auss para o estudo da natureza vinculante das obrigações nas trocas primitivas, da coerção social para a retribuição do presente e da rivalidade envolvida nas transações (:331-332). Embora reveja parcial mente a edição original e acrescente um pequeno prefácio não se refere ao hau, nem à "Introdução" de 1950.

Em 1959, Claude Lévi-Strauss é el eito para o Collège de France e cria o Laboratoire d'A nthropologie Sociale nas dependências daquela instituição. A data é um marco da carreira que haveria de se revelar briIhante nos anos subseqüentes. Desde então Lévi-Strauss publicou uma extensa obra tida consensualmente como importante para a teoria antropológica e seu estruturalismo teve os anos de glória nas décadas de 60 e 70. Ao que parece (pelo menos não localizei), ele não voltou a discutir o ED nem seus supostos equívocos. Mas, à medida que seu prestígio crescia, seus escritos foram adquirindo mana. N este novo contexto, sua interpretação do ED tornou-se referência obrigatória e o interesse pelo próprio trabalho de Mauss ampliou-se de forma notável.

\section{Uma explicação geral: o hau}

Em meados da década de 60, Raymond Firth já cita, em nota, o "valioso comentário de Lévi-Strauss" a respeito do trabalho de M auss (1970[1967]: 24) e expressa, em outra nota (:25) seu acordo com a crítica ao uso do hau 
"como explicação da troca". Insiste, no entanto, retomando os argumentos de 29, de que a Mauss havia errado em sua interpretação do hau.

No final da década, Victor Karady edita pela M inuit três volumes contendo textos de Marcel Mauss. Na apresentação, cita a "Introdução" de Lévi-Strauss e o "Prefácio" de Gurvitch a Sociologie et Anthropologie (1968:III) e assinala que ambos haviam conferido aos trabalhos de Mauss uma significação que correspondia às suas respectivas preocupações, interessados que estavam em traçar e confirmar uma linha de filiação. Não explora, no entanto, o modo como isto foi feito, nem se detém na intepretação acerca dos supostos equívocos de Mauss.

Em 1970, Marshall Sahlins publica um artigo intitulado “L'Esprit du Don", em uma coletânea em homenagem a Lévi-Strauss (Pouillon e $M$ aranda 1970). Ele inicia o texto, que haveria de ser ampliado e republicado mais tarde, com a seguinte afirmação "o conceito central do 'Ensaio sobre o Dom' é a idéia nativa maori do hau" (1974[1970]:149) e acrescenta algumas linhas mais à frente: "o hau maori é erigido numa explicação geral" (:150). O autor refere-se a Lévi-Strauss como um dos críticos da interpretação mausseana do hau (os outros dois sendo Firth e J ohansen) e cita a passagem do "erro" (:153-4). Como não a comenta, pode-se supor que estivesse de acordo com a asserção de que $M$ auss se deixara mistificar pelo ponto de vista nativo21. No mesmo ano, escrevendo na Man, Michel Panoff distingue o ED como "um acontecimento maior na história da teoria antropológica" (1970:60) e cita como evidência a afirmação de Lévi-Strauss, da "Introdução" de 1950, de que ele teria sido um precursores do estruturalismo.

Dois anos mais tarde, a revista L'A rc edita um número dedicado a Mauss, contendo treze textos. O ED aí aparece "como sendo unanimemente considerado a obra-prima do autor" e o princípio oculto da reciprocidade, a regra de funcionamento das prestações totais (Dubar 1972:25). A “Introdução" de Lévi-Strauss já é dada como "clássica" (Condominas 1972:4). Dois dos trabalhos incluídos no volume correspondem a seminários feitos pelos autores em cursos, nos quais certamente o ED estava sendo discutido: é o caso do texto de Gasché para um seminário de J . Derrida na Ecole Normale Supérieure (1972:84) e do organizador do volume, Dennis Hollier, para o um curso de A. Green (Holler 1972:61).

Em livro publicado ainda em 1972, Pierre Bourdieu cita a “Introdução" de Lévi-Strauss para criticar sua teoria das trocas, notadamente as leis mecânicas que regeriam o ciclo de reciprocidade. Chamava ele então a atenção para o intervalo entre o dom e o contra-dom e a dimensão de incerteza que cerca as transações. Estes aspectos das trocas, que já haviam 
sido destacados por Malinowski e M auss, ele haveria de explorar posteriormente para a elaboração de sua teoria da prática (Bourdieu 1980:167189). Bourdieu menciona as reservas de Lévi-Strauss ao ED (1972:222), mas não as discute à luz do texto de M auss. $O$ que parecia lhe interessar era o debate com o então grande "nome" da antropologia francesa.

Em 1976, o ED seria invocado por Parkin como um dos referentes do conceito de troca. $\mathrm{O}$ texto, então, é associado ao princípio da reciprocidade, e a M auss o autor atribui a percepção de um "sistema de troca cultural, envolvendo mulheres, bens, serviços e mensagens" (:163), numa evidente confusão entre o ED e os escritos de Lévi-Strauss. Refere-se ainda às críticas a M auss feitas por Firth em 1929, as quais, por crer estarem amparadas em "trabal ho de campo intenso" (:71), aceita sem reservas.

Em 1979, Cardoso de Oliveira, em apresentação à obra de M auss, procura defender este autor das restrições que Ihe faz Lévi-Strauss, avançando o argumento de que o ED não se limitaria à teoria maori para construir sua teoria do dom (1979:25). Não deixa no entanto de aceitar como dada a interpretação da "Introdução" de 1950, como se efetivamente M auss tivesse usado a "teoria maori" para explicar a troca.

A partir da década de 80, o estruturalismo começou a perder um pouco de sua força, mas não a tese de que o ED continha uma explicação mística da troca. Com o tempo, a tese foi sendo enriquecida com as contribuições de Sahlins e com a recuperação das críticas de Firth de 1929, e cristalizou-se em uma espécie de crença coletiva. Tudo o que havia de arbitrário e conjuntural nas interpretaçõe se foi naturalizando. Operou-se, então, uma indissociação entre o texto de M auss e o hau, os maoris, a reciprocidade e a teoria da troca. Assim, por exemplo, Tambiah refere-se à "formulação mística" (1993[1984]:340) do ED; Guidieri, à "noção de hau que domina o Ensaio" (1984:33); Weiner trata o ED como o texto teórico mais famoso e mais controvertido sobre reciprocidade e só o invoca para reanalisar dados maoris (1992:44-65); Godelier afirma que não pode deixar de endossar a crítica de Lévi-Strauss de que o hau, contrariamente ao que pensava M auss, não pode ser tomado como a explicação da troca (1996:32).

Uma das mais notáveis manifestações da crença é aquela expressa por J ames Carrier, o mesmo que haveria de consagrá-la na enciclopédia citada acima. Assim, em um artigo sobre dons e mercadorias (1995:85108), ele parte de uma crítica ao "modelo mausseano". Admite que o modelo não é de Mauss, mas o utiliza por ser mais prático (:86). O núcleo do modelo seria considerar que o Oriente é o lugar da economia do dom e o Ocidente o da economia da mercadoria. Em contraposição ao que denomina, com justeza, de essencialismos inerentes a estes modelos, 
avança a idéia de que a lógica da mercadoria também funciona no Oriente e a do dom, no Ocidente. Oferece, então, como evidências inúmeros exemplos de pesquisas feitas na Europa, nos Estados Unidos e na Nova Guiné. Se não estivesse tão imbuído da crença, teria consultado o próprio ED e percebido que M auss já apontava nesta direção tanto na abertura do texto, quando se refere à permanência da moral do dom em "nossas" sociedades, quanto na segunda conclusão, quando assinala que o que prevalece entre os trobriandeses é um híbrido, e chama a atenção para a necessidade de complexificação de noções. Sem se dar conta, Carrier explora, de uma maneira bastante sugestiva, indicações contidas no texto do Année Sociologique.

\section{O que se dizer para ser ouvido}

No decorrer da análise dei maior destaque a Lévi-Strauss porque foi a partir de seus escritos que se produziu a inflexão na leitura do ED. Seria equivocado, no entanto, atribuí-la à sua intervenção a respeito das trocas. É preciso distinguir o sentido da ação de Lévi-Strauss ao apontar "erros" de Mauss, que atendia a interesses e ambições pessoais, e os efeitos dela decorrentes. $O$ fato de que sua interpretação do ED tenha servido de base à constituição da crença foi o resultado de um processo cujo princípio de explicação não reside na intenção de Lévi-Strauss. É mais um exemplo dos chamados efeitos da ação não controlados pelo ator, de que falava Max Weber.

O prestígio de Lévi-Strauss certamente esteve na origem, como procurei assinalar, da adesão dos antropólogos às suas interpretações. Uma análise fina da dinâmica do processo de constituição de uma dóxa em relação ao ED demandaria um investimento empírico de grande porte, que escapa à ambição deste texto. Algumas hipóteses a respeito dos mecanismos que teriam contribuído para tanto podem, no entanto, ser indicadas. A difusão da interpretação lévi-strausseana foi obra de antropólogos que se sentiam concernidos com os assuntos da Polinésia e da M elanésia, da troca e da economia: eles certamente anteviram a possibilidade de se associarem simbolicamente ao grande "nome" da antropologia francesa, fazendo referência ao seu trabalho.

Inspirando-me na análise de Elias e Scotson (1994:89-105) sobre a intriga (gossip) em Winston Parva, poderia supor que a dóxa produziu-se a partir de um jogo análogo ao das intrigas de admiração (praise gossip) e as de acusação (blame gossip). Como chamam a atenção os dois auto- 
res, ambas são indissociáveis. A adesão à interpretação lévi-strausseana se enquadraria nas intrigas de admiração; a associação do ED a "aspectos místicos" e a explicações a partir do "ponto de vista nativo" nas de acusação. Uma supõe a outra e elas são visíveis nas referências obrigatórias. Um dos determinantes da intriga é o grau de competição pela audição e atenção dos colegas, o qual, por sua vez, depende das pressões competitivas, particularmente das pressões acerca das rivalidades estatutárias. A possibilidade de obter atenção e aprovação depende da capacidade do que faz a intriga de dizer algo ainda mais desfavorável ao objeto desta ou algo mais leal em termos de sinal de adesão ao grupo (:94-5). No caso em exame, a adesão à tese parece ter sido uma condição para se fazer ouvir ou, como o diria Randall Collins (1998:38-39) atrair a atenção e ser aceito como membro pleno de uma comunidade [de antropólogos].

Um dos efeitos deste tipo de competição, ainda segundo Elias e Scotson, são as distorções que dela decorrem. Nos últimos 30 anos, o ED foi sendo "maorizado", como se apenas da Polinésia ele tratasse. Tornou-se reconhecido como uma "obra-prima", mas marcado idelevelmente por um erro: o da mistificação pelo ponto de vista nativo. De um texto que visava levantar novos problemas e fazer sugestões de pesquisa passou a ser visto como uma teoria, e da reciprocidade, noção que sequer havia retido a atenção de M auss naquele momento. De um trabal ho sobre direito e economia, foi transformado em um estudo de economia. Tudo que nele havia referente ao direito, um tema central para Mauss e para os durkheimeanos, como ressalta Vogt (1983:179), foi sendo progressivamente relegado a segundo plano até ser completamente esquecido pelos antropólogos. Eles se enredaram em querelas sobre o hau e a explicação da troca, perdendo conseqüentemente a perspectiva de que na análise daquela noção do direito maori M auss estava tão-simplesmente dando consistência etnográfica à questão da indissociação entre pessoas e coisas no direito primitivo, um tema já explorado por M ax Weber, em sua sociologia do direito.

Embora a dóxa represente a visão hegemônica acerca ED, há evidências que indicam que antropólogos de diferentes tradições nacionais não a compartilham. Se nos reportarmos à antropologia social britânica, por exemplo, à exceção de Firth que contribuiu para a consolidação da crença, outras figuras expressivas não a consideraram. Edmund Leach, em seu livro sobre Lévi-Strauss, sequer inclui a "Introdução" na bibliografia do autor. Para tratar do que chama de "argumentos" do antropólogo francês sobre a troca, reporta-se ao estudo de 49 , e os trata como se estivessem inscritos na mesma linha de pensamento de M auss e dos funcionalistas britânicos, como Firth (Leach 1996[1970]:121). Em outro trabalho, dedi- 
cado ao estudo da dívida, menciona as contribuições de Radcliffe-Brown, Malinowski, M auss e Lévi-Strauss, mas não se detém em nenhuma delas. Opta por expor sua própria teoria, segundo a qual a troca de presentes é o que o observador vê. Para aqueles que nela estão envolvidos, o que prevalece é o sentimento da dívida, as obrigações morais (1982:149-175). Evans-Pritchard, que conhecera M auss pessoalmente e tinha por ele um grande apreço, distingue o ED como um dos principais trabalhos do amigo e destaca sua contribuição para a comparação sistemática da troca de presentes e sua função na articulação da ordem social. Estas suas observações estão inseridas na nota que escreveu sobre M auss, incluída em livro póstumo (Evans-Pritchard 1981:191-2). Ainda Mary Douglas (1989), em sua introdução a uma tradução inglesa do ED, explora a dimensão interessada dos dons e sequer faz menção a aspectos místicos. Em trabaIho sobre o dom, J onathan Parry (1986) argumenta, contra Sahlins e LéviStrauss, que M auss não oferece em seu trabalho uma explicação geral a partir de uma ideologia específica (maori), mas, sim, coloca em evidência a indissociabilidade entre pessoas e coisas, que estaria presente também nos direitos antigos (:457). A importância deste ponto do ED voltaria a ser destacada pelo mesmo autor em publicação mais recente (Parry e Bloch 1995[1989]:5,11). E fora da Inglaterra, haveria outros autores a mencionar, como por exemplo Ekeh (1974), A ppadurai (1986) e L'Estoile (1996). Estes casos contrários, que não poderiam deixar de ser mencionados, abrem, no entanto, um outro leque de questões, dentre elas a das fronteiras das redes de "intrigas", que escapam aos objetivos deste trabalho.

O que busquei aqui foi identificar as condições sociointelectuais que concorreram para que as idéias contidas no ED fossem apropriadas e reinterpretadas numa determinada direção. $M$ uitos dos aqui citados e que participaram deste processo contribuíram de forma decisiva para o avanço da teoria antropológica, e até mesmo para elucidação de aspectos do trabalho de Mauss. Não esteve em jogo demoli-los, nem negar-lhes o reconhecimento que gozam junto aos colegas. Esta não era a minha questão. Quis tão-somente, através da análise do que sucedeu com o texto de M auss, colocar em evidência mecanismos sociais que operam no processo de construção de teorias no âmbito da antropologia, na conformação de representações acerca de textos e na sua consagração. Fiz um estudo de caso contendo indicações de método a serem testadas no exame de outros episódios da história da disciplina que, como este, estão a merecer uma apreciação mais distanciada e menos encantada. 
Lygia Sigaud é Professora do PPGAS do Museu Nacional, UFRJ . Publicou trabalhos a partir de pesquisas realizadas na região das grandes plantações canavieiras de Pernambuco; em áreas de deslocamento forçado de populações em decorrência da construção de barragens; sobre usos sociais do direito; e sobre história social da antropologia, a partir do estudo do caso de Edmund Leach. Desenvolve atualmente pesquisas a respeito das condições sociais de possibilidade da autonomia intelectual e a acerca de transformações sociais em curso na mesma zona canavieira.

\section{Notas}

* Uma versão preliminar deste texto foi apresentada durante o Seminário Ciências Sociais, Estado e Sociedade, realizado no M useu Nacional em setembro de 1997. Agradeço os comentários então feitos por Benoît de L'Estoile, Alban Bensa, Federico N eiburg, Márcio Goldman, Carlos Fausto e Antonio Carlos de Souza Lima. As idéias que serão aqui desenvolvidas começaram, no entanto, a ser esboçadas por ocasião de curso oferecido no Programa de Pós-Graduação em Antropologia Social do M useu N acional, no segundo semestre de 1996, e, finalmente, amadurecidas em outro curso, no primeiro semestre de 1999. Estendo também aos alunos de ambos os cursos os meus agradecimentos: foi interagindo com eles que logrei avançar na construção de meu objeto.

1 Pude me beneficiar, para a elaboração deste texto, do volume expressivo de informações reunidas por Fournier em sua biografia de Mauss.

2 A pesquisa visava o exame das condições sociais nas quais eclodiam e eram regulados conflitos entre trabalhadores rurais e patrões na zona canavieira de Pernambuco (Sigaud 1994,1996a e 1999). Foi apoiada sucessivamente pela Fundação Ford, Finep e CNPq.

3 Coloquei entre aspas os pronomes "nossos" porque não me parece que a sociedade em que vivo faça parte do universo pensado por Mauss.

4 Em 1930, Mauss calculava que das dez a onze mil páginas dos quatorze volumes do Année Sociologique, havia escrito duas mil e quinhentas, e destaca outras setecentas de contribuições bibliográficas (M auss 1979[1930]:142).

5 As resenhas eram, para o grupo reunido em torno de Durkheim, uma estratégia privilegiada de intervenção nos debates nas ciências sociais da época, como o destaca Karady (1983:87). 
6 Nascido na Nova Zelândia e tendo lá se graduado em economia, Firth chega a Londres em 1924 para prosseguir os estudos na mesma disciplina. A antropologia era então para ele uma espécie de hobby. Acaba elaborando uma tese entre a economia e a antropologia (Parkin, 1988: 330-331) e se torna, em 1927, o primeiro doutor em antropologia social da Inglaterra.

7 Segundo seu biógrafo, M auss teria apenas feito uma comunicação no Institut Français d'A nthropologie, em 1926, a respeito das "parentés à plaisanterie", fenômenos que se assemelhavam ao potlatch com suas rivalidades de generosidade (Fournier, 1994:525).

8 Os textos aparecem na bibliografia dos cursos, conforme foi possível constatar por meio da consulta aos anuários escolares (LSE, 1937-38, 1938-39; 1947-48).

9 Por ser de origem judaica, M auss sofreu perseguição durante a ocupação nazista. Teve de afastar-se da Ecole Pratique e do Collège de France e sua casa foi tomada por oficiais alemães. Segundo Fournier, ao final da guerra encontravase alquebrado. Entrou, em seguida, em uma fase de silêncio e progressivo enfraquecimento físico (1994:721-67).

10 Sobre a reivindicação da herança mausseana, ver Karady (1968:I-VI) e Fournier (1994:760-66). É Karady quem chama a atenção para o fato de que a preocupação em reabilitar a Escola via M auss teria funcionado como critério na seleção dos textos incluídos na coletânea. A ssim, só foram escolhidos textos da "maturidade" de M auss e deixados de lado outros mais conformes à ortodoxia durkheimeana, provavelmente para tornar o ensinamento da escola mais aceitável ao gosto da época (: V). Karady.

11 Tal projeto só viria a ser levado a cabo quase duas décadas depois, por

$12 \mathrm{Não}$ encontrei nos depoimentos autobiográficos de Lévi-Strauss, nem na biografia de Mauss (Fournier, 1994) evidências de uma relação estreita entre eles. Há apenas registros de cartas de Lévi-Strauss a M auss, de recomendações de Mauss e de referências ao fato de que acompanhava o trabalho do jovem etnólogo, assim como de outros que se interessavam pela disciplina.

13 Na primeira edição não foi incluído o "Ensaio sobre as Variações Sazonais das Sociedades Esquimós. Estudo de M orfologia Social". Este texto só foi incorporado a partir da terceira edição de Sociologie et Anthropologie, de acordo com o desejo expresso por Gurvitch antes de sua morte (M auss, 1991:VI). Ele não foi, por conseguinte, objeto dos comentários de Lévi-Strauss.

14 Foi também a partir de trabalho de campo feito no Brasil que Lévi-Strauss escreveu seus primeiros textos de cunho etnológico que haveriam de lhe valer o reconhecimento como um profissional da disciplina. Ver, a respeito, Peixoto (1998: 81-87). 
15 Segundo Karady (1968:VI; nota 11) “após a morte de Durkheim em 1917 sua cátedra de Ciência da Educação e Sociologia foi várias vezes transformada, a cátedra de Sociologia só tendo sido criada em 1932. Seus titulares foram, por ordem de sucessão: P. Fauconnet, M. Halbwachs, G. Davy [...]", isto é, pessoas diretamente ligadas a Durkheim e a Mauss.

${ }^{16}$ Criado no século XVI, o Collège de France tornou-se uma instituição de consagração suprema como o assinala Charle (1986:403). No século XX, conquistar uma cátedra era a ambição daqueles que não desejavam assumir as tarefas pesadas do ensino universitário. Nos pós-guerra a concorrência se acirra, segundo este autor. Entende-se, assim, a dificuldade enfrentada por Lévi-Strauss.

17 Lévi-Strauss o afirma textualmente em entrevista concedida na década de 70. Cf. Clément e Grisoni (1971: 24).

18 Este episódio parece ajustar-se ao que chama a atenção Norbert Elias quando afirma que o conhecimento sofre algumas deformações decorrentes do fato de que se constitui também em um meio para que produtores mantenham e aumentem seu poder e seu status dentro e fora dos establishments científicos (1982:52-53)

19 O "nome", como o assinala Pierre Bourdieu (1984), é o bem mais precioso no mundo acadêmico.

20 Para a análise da trajetória de Leach que serve de base à comparação, ver Sigaud (1996a).

21 Sahlins havia passado dois anos em Paris, entre 1967 e 1969, período áureo do estruturalismo. Segundo interpretação de Kuper (1999:164), data de então sua ruptura com o evolucionismo marxista e sua conversão para uma espécie de determinismo cultural. 


\section{Referências bibliográficas}

APPADURAI, Arjun (ed.). 1990 [1986]. The Social Life of Things. Commodities in Cultural Perspective. Cambridge: Cambridge University Press

AUGÉ, M arc. 1999. “Le Triangle Anthropologique: Mauss, Bataille, LéviStrauss". Critique, LV:620-621.

BENVENISTE, Émile. 1951. “Don et Echange dans le Vocabulaire IndoEuropéen". Année Sociologique, 3a Série (1948-1949).

BOHANNAN, Paul. 1955. "Some Principles of Exchange and Investment among the Tiv". American Anthropologist, 57(1):60-70.

BOURDIEU, Pierre. 1972. Esquisse d'une Théorie de la Pratique. Genève/ Paris: Librairie Droz. . 1980. Le Sens Pratique. Paris: Editions de $M$ inuit.

.1984. Homo Academicus. Paris: Editions de $M$ inuit.

CARRIER, J ames. 1995. "Maussian Occidentalism: Gift and Commodity Systems". In: J . Carrier (ed.), Occidentalism. Images of the West. Oxford: Clarendon Press. pp. 85-108. . 1997. "Exchange". In: A. Barnard e J . Spencer (eds.), Encyclopedia of Social and Cultural Anthropology. London: Routledge. pp. 218-220.

CLEMENT, C. e GRISONI, D. A. 1971. "Lévi-Strauss: Autoportrait". Magazine Littéraire, 58.

CHARLE, Cristophe. 1986. "Le Collège de France". In: P. Nora (org.), Les Lieux de Mémoire. La Nation (Vol. II). Paris: Gallimard. pp. 389-424.

COHEN-SOLAL, Annie. 1999. "'Claude Lévi-Strauss' aux Etats-Unis: 'Des Portes Donnant Accès à d'Autres Mondes et à Tous les Temps'". Critique, LV: 13-25.
COLLINS, Randall. 1998. The Sociology of Philosophies. A Global Theory of Intellectual Change. Cambridge, MS: The Belknap Press of Harvard University Press.

CONDOMINAS, Georges. 1972. “M arcel Mauss et I'Homme de Terrain". L'Arc, 48:3-6.

DOUGLAS, Mary. 1989. “II n'y a pas de Don Gratuit. Introduction à I'Edition Anglaise de l'Essai sur le Don de M arcel Mauss". La Révue Mauss, 2osemestre, 4:99-115.

DUBAR, Claude. 1972. "Retour aux Textes". L'Arc, 48:23-27.

DUM ONT, Louis. 1972 [1952]. “Une Science en Devenir". L'Arc, 48:8-21.

ELIAS, Norbert. 1982. "Scientific Establishments". In: N. Elias, H. Martins e R. Welley (eds.), Scientific Establishments and Hierarchies. Dobrecht, Boston, London: D. Reidel Publishing Company. pp. 3-69. e SCOTSON, J ohn L. 1994 [1965]. The Established and the Outsiders. A Sociological Enquiry into Community Problems. London, Thousand Oaks, New Delhi: Sage Publications.

EKEH, Peter. 1974. Social Exchange Theory. The Two Traditions. London: Heinemann Educational Books Ltd.

EVANS-PRITCHARD, Edward. 1972 [1954]. “'Introduction' à L'Essai sur le Don”. L'Arc, 48:28-31. .1981. History of Anthropological Thought. London, Boston: Faber and Faber.

FIRTH, Raymond. 1959 [1929]. Economics of the New Zealand Maori. Wellington, New Zealand: R. E. Owen, Government Printer. .1965[1939]. Primitive Polynesian 
Economy. London: Routledge \& Keagan Paul. 2a edição.

. 1967 [1970]. "Themes in Economic Anthropology. A General Comment". In: R. Firth (ed.), Themes in Economic Anthropology. London: Tavistock Publications. pp. 1-28. .1975. "An Appraisal of Modern Social Anthropology". Annual Review of Anthropology, vol. 4:1-25.

FOURNIER, M arcel. 1994. Marcel Mauss. Paris: Fayard.

GASCHÉ, Rodolphe. 1972. “L'Echange Héliocentrique". L'Arc, 48:70-84.

GERNET, Louis. 1982 [1951]. “Droit et Prédroit en Grèce Ancienne". In: Droit et Institution en Grèce Ancienne. Paris: Flammarion. pp. 7-119.

GODELIER, Maurice. 1996. L'Enigme du Don. Paris: Fayard.

GUIDIERI, Remo. 1984. L'Abondance des Pauvres. Paris: Editions du Seuil.

GURVITCH, Georges. e MOORE, Wilbert. 1965 [1946]. La Sociologia del Siglo XX. Barcelona: El Ateneo.

HERITIER, Françoise. 1999. “La Citadelle Imprenable". Critique, LV:6183.

HERTZ, Robert. 1988 [1922]. Le Péchê et I'Expiation dans les Sociétés Primitives. Les Cahiers de Gradhiva 6. Paris: J ean Michel Place.

HOLLIER, Dennis. 1972. “M alaise dans la Sociologie". L'Arc, 48:55-61.

J OHANSEN, J. Prytz. 1954. The Maori and his Religion in its Non-ritualistic Aspects. Copenhagen: Ejnar Munksgaard.

JUILLERAT, Bernard. 1993. “Richard Thurnwald et la Mélanesie. Réciprocités, Hiérarchies, Evolutions". Gradhiva. Revue d'Histoire et d'Archives de l'A nthropologie, 14:15-40.
KARADY, Victor. 1968. "Présentation". In: M. Mauss, Oeuvres. 1. Les Fonctions Sociales du Sacré. Paris: Les Editions de Minuit. .1983. "The Durkheimians in Academy. A Reconsideration". In: P. Besnard (org.), The Sociological Domain. The Durkheimians and the Founding of French Sociology. Cambridge/Paris: Cambridge University Press \& Editions de la Maison des Sciences de l'Homme. pp. 71-89.

KUPER, Adam. 1999. Culture. The Anthropologists' Account. Cambridge, MS: Harvard University Press.

LEACH, Edmund. 1951. “The Structural Implications of Matrilineal CrossCousin Marriage". J ournal of the Royal Anthropological Institute, vol 81:23-55.

. 1955. “Review of M. Mauss The Gift". Man, 55:30. . 1982. Social Anthropology. N ew York/Oxford: Oxford University Press. . 1996 [1970]. Lévi-Strauss. London: Fontana Press (quarta edição) . 1996 [1954]. Sistemas Políticos da Alta Birmânia. São Paulo: Edusp.

LEFORT, Claude. 1967 [1951]. “A Troca ea Luta dos Homens". In: C. H. Escobar (ed.), O M étodo Estruturalista. Rio de J aneiro: Zahar Editores. pp. 64-79.

LÉVI-BRHUL, Henry. 1951. “In Memoriam. Marcel M auss". Année Sociologique, 3a Série (1948-1949).

LÉVI-STRAUSS, Claude. 1965 [1946]. “La Sociologia Francesa”. In: G. Gurvitch e W. Moore (orgs.), La Sociologia del Siglo XX. Barcelona: El Ateneo. pp. 1-31.

1967 [1949]. Les Structures Elémentaires de la Parenté. Paris: M outon. 
e D. ERIBON. 1988. De Près et de Loin. Paris: Editions Odile J acob. . 1991 [1950]. “Introduction à I'Oeuvre de Marcel M auss". Sociologie et Anthropologie. Paris: PUF. pp. IXLII.

L'ESTOILE, Benoît de. 1996. “Peut-on Aimer ses Patrons? Langage du Don, Langage du Droit et Domination Personnelle". Communication au Colloque Marcel Mauss Today, Oxford. Ms.

LONDON SCHOOL OF ECONOMICS. 1937-38; 1938-39; 1947-48. The Calendar of the LSE. London.

LOWIE, Robert. 1969 [1936]. Traité de Sociologie Primitive. Paris: Payot. . 1971 [1937]. Histoire de I'Ethnologie Classique. Paris: Payot.

MALIN OWSKI, Bronislaw. 1961 [1922]. Argonauts of the Western Pacific. New York: E. P. Dutton \& Co., Inc. .1970 (1926). Crime and Custom in Savage Society. London: Routledge \& Kegan Paul, Ltd. .1935. Coral Gardens and their Magic. London: George Allen \& Unwin Ltd.

MAUSS, Marcel. 1969. Oeuvres 3. Cohésion Sociale et Divisions de las Sociologies, vol. III. Paris: Minuit. . 1991 [1923-24]. “Essai sur le Don. Forme et Raison de l'Echange dans les Sociétés Archaïques". Sociologie et Anthropologie. Paris: PUF. pp. 145-171.

. 1979 [1930]. “L'Oeuvre de M auss par Lui-M ême". Revue Française de Sociologie, XX(1):209-220.

MERLEAU-PONTY, M aurice. 1960. “De M auss à Lévi-Strauss". In: Signes. Paris: Gallimard.

MURPHY, Robert. 1972. Robert H. Lowie. New York: Columbia University Press.

OLIVEIRA, Roberto Cardoso de. 1979. “Introdução a uma Leitura de
Mauss". In: Mauss. São Paulo: Editora Ática. pp. 7-50.

PANOFF, Michel. 1970. “Marcel Mauss's The Gift Revisited”. Man, 5(1):60-70.

PARKIN, David. 1976. "Exchanging Words". In: B. Kapferer (ed.), Transaction and Meaning. Direction in the Anthropology of Exchange and Symbolic Behaviour. Philadelphia: Institute for the Study of Human Issues, Inc. pp.163-190.

.1988. "An Interview with Raymond Firth". Current Anthropology, 29(2):327-341.

PARRY, J onathan. 1986. "The Gift, the Indian Gift and the "Indian Gift'". $M$ an (N.S.)21:453-73.

e BLOCH, Maurice. 1995 [1989]. Money and the Morality of Exchange. Cambridge: Cambridge University Press.

PEIXOTO, Fernanda. 1998. “Lévi-Strauss no Brasil: A Formação do Etnólogo". $M$ ana, Estudos de Antropologia Social, 4(1):79-107.

POUILLON, J ean e MARANDA, Pierre. 1970. Echanges et Communications. Melanges Offerts à Claude LéviStrauss à l'Occasion de son Anniversaire. Paris: Mouton.

SAHLINS, M arshall. 1974 [1970]. "The Spirit of the Gift". Stone Age Economics. London: Tavistock.

SIGAUD, Lygia. 1994. “Direito e Gestão de Injustiças". Antropologia Social. Comunicações do PPGAS, n. 4:139170.

.1996a "Direito e Coerção Moral no M undo dos Engenhos". Estudos Históricos, 18:361-388.

. 1996b. “Apresentação”. In: E. Leach (ed.), Sistemas Políticos da Alta Birmânia. São Paulo: Edusp. pp. 9-45. . 1999. “Les Paysans et le Droit: Le Mode J uridique de Règlement des Conflits". I nformation sur les Sciences Sociales, 38(1):113-147. 
TAM BIAH, Stanley J . 1993 [1984]. The Budhist Saints of the Forest and the Cult of Amulets. A Study on Charisma, Hagiography, Sectarianism, and Millennial Budhism. Cambridge: Cambridge University Press. VEYNE, Paul. 1976. Le Pain et le Cirque. Sociologie Historique d'un Pluralisme Politique. Paris: Editions du Seuil.

VOGT, Paul. 1983. “Obligation and Right: The Durkheimians and the Sociology of Law". In: P. Besnard (ed.), The Sociological Domain and the Founding of French School. Cambridge and Paris: Cambridge University Press/Editions de la Maison des Sciences de I'Homme. pp. 177-198.

WEBER, Max. 1986. Sociologie du Droit. Paris: PUF.

WEINER, Annete. 1992. Inalienable Possessions. The Paradox of KeepingWhile-Giving. Berkeley: University of California Press. 
Resumo

A partir dos anos 60, antropólogos de diferentes tradições nacionais passaram a convergir no sentido de considerar que o texto de M arcel M auss, "Ensaio sobre o Dom", contivesse uma teoria da troca, que atribui à identificação entre a coisa dada e o espírito do doador o princípio de explicação das transações. Esta interpretação contrasta com a que tiveram os contemporâneos de Mauss, os quais resgataram do trabalho suas dimensões relativas ao direito, às obrigações e às prestações totais. Partindo desta constatação, o artigo problematiza o destino do ensaio e busca torná-lo inteligível. Para tanto examina as condições sociointelectuais que contribuíram para que se produzisse a inflexão na leitura e a consolidação de uma espécie de crença coletiva em relação ao trabal ho. Através deste estudo de caso, a autora identifica mecanismos que operam no processo de construção de teorias, na conformação de representações acerca de textos e na sua consagração no âmbito da antropologia.

\section{Abstract}

From the 1960s, anthropologists of different national traditions came to share the view that Marcel Mauss's text, "Essay on the Gift," contained a theory of exchange which takes the identification between the thing given and the spirit of the donor as the explanatory principle of transactions. This interpretation contrasts with that held by Mauss's contemporaries, who lifted from the work aspects relating to law, obligations and total prestations. Starting from this fact, the article problematizes the essay's fate and seeks to make it intelligible. To this end, it examines the socio-intellectual conditions which contributed to producing this inflection in the readings of the work and the consolidation of a kind of collective belief concerning it. Through this case study, the author identifies mechanisms which operate in the process of constructing theories, in the conformity found in representations of certain texts, and in the consecration of these works in the area of anthropology. 